\title{
Nitrogen-doped Carbon Paper as Electrodes for Vanadium Redox Flow Batteries
}

\author{
HE Zhang-Xing ${ }^{1,2}$, LIU Jian-Lei ${ }^{2}$, HE Zhen ${ }^{2}$, LIU Su-Qin ${ }^{2}$ \\ (1. School of Chemical Engineering, Hebei United University, Tangshan 063009, China; 2. Key Laboratory of Resources Chemistry \\ of Nonferrous Metals, Ministry of Education, School of Chemistry and Chemical Engineering, Central South University, Changsha \\ 410083, China)
}

\begin{abstract}
To improve the electrochemical activity of carbon paper (CP) for vanadium redox flow batteries, $\mathrm{CP}$ was modified by heat treatment in atmosphere of $\mathrm{NH}_{3}$ at 600 (NCP-600) and $900^{\circ} \mathrm{C}$ (NCP-900), respectively. The FTIR results indicate that the nitrogenous groups have been introduced on the surface of CP by modification successfully. Compared with the pristine sample, the water contact angle of NCP-900 decreases from $120.5^{\circ}$ to $99.7^{\circ}$, indicating the improved hydrophilicity of CP by nitrogen doping. The SEM results show that there is no obvious morphology change on the surface of CP after nitrogen doping, which do not affect the mechanical property. The electrochemical activity of $\mathrm{CP}$ is enhanced significantly by nitrogen doping. The oxidation current peak of $\mathrm{V}(\mathrm{IV}) / \mathrm{V}(\mathrm{V})$ couple on NCP-900 is 92.1 mA, much higher than that of pristine sample $(68.9 \mathrm{~mA})$. The cells with NCP-900 and pristine sample as electrodes were assembled and the charge-discharge performance was evaluated. The energy efficiency of cell with NCP-900 as electrode at a current density of $20 \mathrm{~mA} / \mathrm{cm}^{2}$ is $83.73 \%, 2.59 \%$ larger than that with the pristine sample. The improved electrochemical performance of nitrogen-doped carbon paper is due to the increased active sites and the enhanced hydrophilicity provided by the introduced nitrogenous groups.
\end{abstract}

Key words: vanadium redox flow batteries; nitrogen doping; carbon paper; kinetics

With massive consumption of fossil fuels, the growing environmental pollution and limited reserves have required use of new energies, such as solar energy, wind energy, etc ${ }^{[1-2]}$. However, it is difficult to integrate these new energies into electrical supply grids due to the intermittent varied nature of these resources ${ }^{[3]}$. Large-scale electrical energy storage system, such as flywheels, compressed air, superconducting magnetic energy storage and redox flow batteries ${ }^{[4-7]}$, can promote a new opportunity for the wide commercial application of new energies. The vanadium redox flow batteries (VRFB), originally proposed by Skyllas-Kazacos, et $a l^{[8-10]}$ have been investigated extensively ${ }^{[11-13]}$. It is believed to be one of the most important energy storage systems of intermittent renewable energy as its many advantages, including high energy efficiency, long cycle life, flexible design, low maintenance cost and environmental friendship $^{[8,11-13]}$. In the VRFB system, $\mathrm{V}(\mathrm{IV}) / \mathrm{V}(\mathrm{V})$ and $\mathrm{V}$ (II)/V(III) redox couples are employed as active species in the positive and negative side, respectively, which are separated by ion-exchange membrane. The reaction place of charge transfer is provided by the electrode. A standard voltage of $1.26 \mathrm{~V}$ is produced in VRFB system through the following reactions ${ }^{[3]}$.

$$
\begin{gathered}
\text { Cathode : } \mathrm{VO}^{2+}+\mathrm{H}_{2} \mathrm{O}-\mathrm{e}^{-} \underset{\text { Discharge }}{\stackrel{\text { Charge }}{\longrightarrow}} \mathrm{VO}_{2}^{+}+2 \mathrm{H}^{+} E^{0}=1.00 \mathrm{~V} \text { (1) } \\
\text { Anode : } \mathrm{V}^{3+}+\mathrm{e}^{-} \underset{\text { Discharge }}{\stackrel{\text { Charge }}{\leftrightarrows}} \mathrm{V}^{2+} \quad E^{0}=-0.26 \mathrm{~V} \\
\text { Cell }: \mathrm{VO}^{2+}+\mathrm{H}_{2} \mathrm{O}+\mathrm{V}^{3+} \stackrel{\text { Charge }}{\stackrel{\text { Discharge }}{\longrightarrow}} \mathrm{VO}_{2}^{+}+2 \mathrm{H}^{+}+\mathrm{V}^{2+} E^{0}=1.26 \mathrm{~V}
\end{gathered}
$$

The electrodes play an important role in VRFB, because the electrochemical reaction takes place on the surface of the electrodes, although they do not act as active species directly ${ }^{[14]}$. Consequently, choosing suitable electrode materials is of fundamental importance for good electrochemical performance of VRFB. Currently, the most widely used electrodes for VRFB are PAN-graphite felt, due to its wide operation potential range, low cost and excellent stability ${ }^{[15-16]}$. However, the poor hydrophilicity and electrochemical activity of these electrodes limit the energy efficiency and power density for the VRFB system ${ }^{[17-18]}$. Until now, a series of modification methods have been reported to improve the electrochemical activity of electrodes, such as acid treatment ${ }^{[19]}$, heat treatment ${ }^{[12]}$, electrochemical oxidation ${ }^{[20]}$, and introducing functional 
groups as well as electrocatalysts ${ }^{[21-23]}$.

Carbon paper (CP), as an electrode for VRFB, has been paid much attention because of the relatively smaller volume and higher power density. However, the carbon paper also has bad hydrophilicity and electrochemical activity. $\mathrm{Liu}^{[24-25]}$ enhanced the electrochemical activity of $\mathrm{CP}$ by acid treatment and heat treatment, mainly owing to the increase of $-\mathrm{COOH}$ functional groups. Recently, Shao ${ }^{[22]}$ investigated the electrochemical performance of nitrogen-doped mesoporous carbon in VRFB system and found that the electrocatalytic kinetics of the V(IV)/V(V) redox couple was significantly enhanced by nitrogen doping. Huang ${ }^{[23]}$ and $\mathrm{Liu}^{[26]}$ modified the graphite felt and carbon paper by hydrothermal ammoniated method and the enhanced electrochemical performance was acquired. However, the nitrogen-doped mesoporous carbon is difficult to be applied in practice due to its structure. And the strict requirements for device and tedious treatment time limit the application of hydrothermal ammoniated treatment. In this paper, the carbon paper as electrode was modified by heat treatment in atmosphere of $\mathrm{NH}_{3}$ with advantages, such as short treating time, convenient operation and suitability for large batch production.

\section{Experimental}

\subsection{Materials preparation and characterization}

The carbon paper (HCP030N, $0.29 \mathrm{~mm}$, Shanghai Hesen Ltd. Co., China) was modifed by heat treatment in atmosphere of $\mathrm{NH}_{3}$. Prior to heating, $\mathrm{NH}_{3}$ was passed into the tubular furnace for $30 \mathrm{~min}$ at a flow rate of $1.0 \mathrm{~L} / \mathrm{min}$ to eliminate air. Then the carbon paper was heated in the tubular furnace via heating ramps of $5^{\circ} \mathrm{C}$ from ambient temperature to $900{ }^{\circ} \mathrm{C}$ and kept at $900{ }^{\circ} \mathrm{C}$ for $150 \mathrm{~min}$ (NCP-900) in atmosphere of $\mathrm{NH}_{3}$ at a flow rate of $0.3 \mathrm{~L} / \mathrm{min}$. The pristine carbon paper and the carbon paper heated at $600^{\circ} \mathrm{C}$ (NGF-600) were used as comparison.

The surface morphologies of the samples were characterized with a field-emission scanning electron microscope (Nova NanoSEM230, Czech) at an acceleration voltage of $10 \mathrm{kV}$. Fourier transformation infrared spectroscopy (FTIR) was recorded from dried $\mathrm{KBr}$ disks containing the crushed carbon paper powder on a NICOLET 6700 instrument (Thermo Fisher Scientific) to characterize groups on the carbon paper. The wetting properties were characterized by water contact angle measurement on the contact angle goniometer (JC2001).

\subsection{Electrochemical measurements}

Cyclic voltammetry tests were performed using the RST5200 electrochemical workstation (Zhengzhou Shiruisi Technology Co., Ltd., China). A three-electrode system was used to measure the electrochemical performance of carbon paper, with a Pt electrode $(2.0 \mathrm{~cm} \times 2.0 \mathrm{~cm})$ as the counter electrode, a saturated calomel electrode (SCE) along with salt bridge as the reference electrode and the different carbon paper with an area of $1.0 \mathrm{~cm}^{2}$ as the working electrode. Prior to each measurement, the carbon paper was soaked in the electrolyte for $4 \mathrm{~h}$. The reference electrode was washed with distilled water, and the solution in salt bridge was replaced before measurements. Cyclic voltammetry was carried out between $0 \mathrm{~V}$ and $1.6 \mathrm{~V}$ vs $\mathrm{SCE}$ at a scan rate of $10 \mathrm{mV} / \mathrm{s}$, and the corresponding electrolyte is $1.0 \mathrm{~mol} / \mathrm{L} \mathrm{V}(\mathrm{IV})$ in $3 \mathrm{~mol} / \mathrm{L} \mathrm{H}_{2} \mathrm{SO}_{4}$. Unless otherwise specified, the electrode potentials are reported relative to the SCE electrode.

\subsection{Charge-discharge test}

Constant current charge-discharge tests for a single static cell were carried out between $0.7 \mathrm{~V}$ and $1.7 \mathrm{~V}$ at a current density of $20 \mathrm{~mA} / \mathrm{cm}^{2}$ with a battery test system (CT2001A-10V/2A, Wuhan Land Co., China). $1.2 \mathrm{~mol} / \mathrm{L}$ $\mathrm{V}(\mathrm{III})+3 \mathrm{~mol} / \mathrm{L} \mathrm{H}_{2} \mathrm{SO}_{4}$ and $1.2 \mathrm{~mol} / \mathrm{L} \mathrm{V}(\mathrm{IV})+3 \mathrm{~mol} / \mathrm{L}$ $\mathrm{H}_{2} \mathrm{SO}_{4}$ were used as the positive and negative electrolyte in the cell, respectively. The carbon paper $(3.0 \mathrm{~cm} \times 3.0 \mathrm{~cm})$ was soaked in the corresponding electrolyte for $24 \mathrm{~h}$ at room temperature before serving as electrodes. A perfluorinated ion-exchange membrane (Best Industrial \& Trade Co., Ltd., China) was employed as the separator for electrolytes. Before each test, the charge-discharge tests were performed at a current density of $10 \mathrm{~mA} / \mathrm{cm}^{2}$ to activate the electrode for one cycle. The CP and NCP-900 as electrodes were used as comparison.

\section{Results and discussion}

\subsection{Materials characterization}

The surface morphologies of different carbon paper are shown in Fig. 1. SEM analysis is performed to characterize the features of CP and NCPs. As shown in Fig. 1, there is no obvious change on the surface of carbon paper after treatment. However, the NCPs are more smooth than CP, which may be attributed to the reaction between $\mathrm{NH}_{3}$ and carbon paper, which removes some contaminants on the surface of carbon paper that may hinder electron transfer ${ }^{[12]}$. There are fewer contaminants on NCP-900, compared with NCP-600, which is due to stronger reaction at higher heat treatment temperature.

Fourier transform infrared spectra of different carbon papers, recorded in the range of 4000-760 $\mathrm{cm}^{-1}$, are shown in Fig. 2. As for the CP, the peaks at 3446 and $2920 \mathrm{~cm}^{-1}$ are assigned to the stretching vibration of $-\mathrm{OH}$ and $\mathrm{C}-\mathrm{H}$, respectively. The peaks at 1391 and $1090 \mathrm{~cm}^{-1}$ are attributed to the bending vibration of $\mathrm{C}-\mathrm{H}$ and stretching vibration 

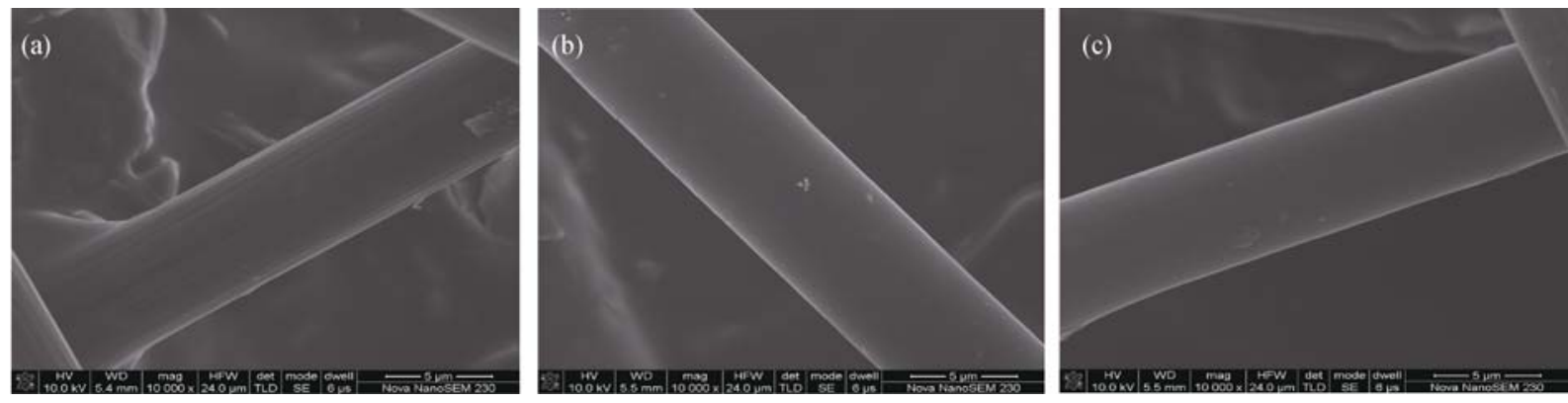

Fig. 1 Surface morphologies of different carbon paper

(a) CP; (b) NCP-600; (c) NCP-900

of $\mathrm{C}-\mathrm{O}$, respectively. Compared with $\mathrm{CP}$, a stronger absorption peak within $3300-3500 \mathrm{~cm}^{-1}$ appears in NCPs due to the overlap of the stretching vibration of $-\mathrm{NH}_{2}$ and $-\mathrm{OH}^{[27]}$. The new peak at about $1638 \mathrm{~cm}^{-1}$ is corresponded to the deformation vibration of $\mathrm{N}-\mathrm{H}$. The peak at $2920 \mathrm{~cm}^{-1}$ of the NCPs corresponded to the stretching vibration of $\mathrm{C}-\mathrm{H}$ becomes weaker, as some $\mathrm{C}-\mathrm{H}$ was substituted by $-\mathrm{NH}_{2}$. The peak at $1383 \mathrm{~cm}^{-1}$ is assigned to the stretching vibration of $\mathrm{N}-\mathrm{O}$, owing to the interreaction between $\mathrm{O}$ and $\mathrm{N}$ atoms at high temperature. The nitrogen doping degree is relevant to the heat treatment temperature, so the NCP-900 has stronger peaksat about 3444 and $1638 \mathrm{~cm}^{-1}$, compared with the NCP-600. The FTIR results indicate that the nitrogenous groups are introduced on the surface of carbon paper successfully by heat treatment in atmosphere of $\mathrm{NH}_{3}$.

\subsection{Wetting property}

The wetting properties of carbon papers were characterized by water contact angle test. The cross-sectional views of water droplets on the surface of different carbon papers are presented in Fig. 3. The smaller contact angle reflects the enhancement of wetting properties for carbon paper. As can be seen in Fig. 3, the contact angle of NCP-600 and NCP-900 are $105.3^{\circ}$ and $99.7^{\circ}$, respectively, both smaller than that of $\mathrm{CP}\left(120.5^{\circ}\right)$. It indicates that nitrogen doping can enhance the hydrophilicity of carbon

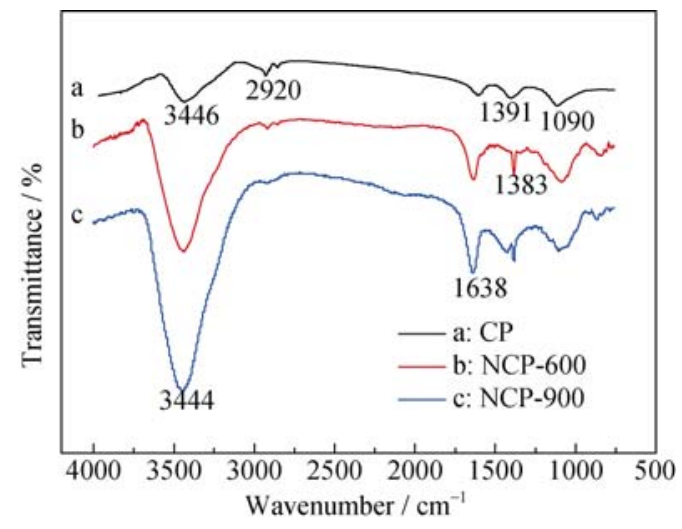

Fig. 2 FTIR spectra of different carbon paper (a) CP; (b) NCP-600; (c) NCP-900 paper, and NCP-900 has better hydrophilicity between two NCPs. This results can be explained as follows. The nitrogenous functional groups, such as $-\mathrm{NH}_{2}$, introduced by heat treatment in atmosphere of $\mathrm{NH}_{3}$, can improve the hydrophilicity of carbon paper. And the lower contact angle of NCP-900 is attributed to higher nitrogen doping degree at higher heat treatment temperature.

\subsection{Cyclic voltammetry}

Figure 4 shows the cyclic voltammograms of $1.0 \mathrm{~mol} / \mathrm{L}$ $\mathrm{V}(\mathrm{IV})$ in $3.0 \mathrm{~mol} / \mathrm{L} \mathrm{H}_{2} \mathrm{SO}_{4}$ solution with different carbon papers as working electrode. The relevant electrochemical data obtained from Fig. 4 are listed in Table 1. It can be seen from Table 1 that the peak currents for oxidation and reduction reaction both increase after heat treatment in atmosphere of $\mathrm{NH}_{3}$. The oxidation peak currents for $\mathrm{V}(\mathrm{IV}) / \mathrm{V}(\mathrm{V})$ couple with NCP-600 and NCP-900 are 83.8 and $92.1 \mathrm{~mA}$, much higher than that with $\mathrm{CP}(68.9 \mathrm{~mA})$. The result demonstrates that the electrochemical activity of $\mathrm{V}(\mathrm{IV}) / \mathrm{V}(\mathrm{V})$ redox couple is improved by nitrogen doping. Compared with $\mathrm{CP}$, the peak potential interval decreases and the ratio of reduction peak current to oxidation peak current is more close to 1 , which proves that nitrogen doping could enhance the electrochemical reversibility. As all the tests were performed in the same conditions, the improved electrochemical performance of carbon paper is attributed to the introduction of nitrogenous groups, which can be known from the results of FTIR. On the one hand, according to the results of density functional theory calculations, carbon atoms adjacent to nitrogen atoms possess a high positive charge density to counterbalance the strong electronic affinity of the nitrogen atoms ${ }^{[23]}$. The "positively charged" carbon atoms activated by nitrogen atoms can be employed as the active sites. In addition, the introduced nitrogenous groups can enhance the hydrophilicity,

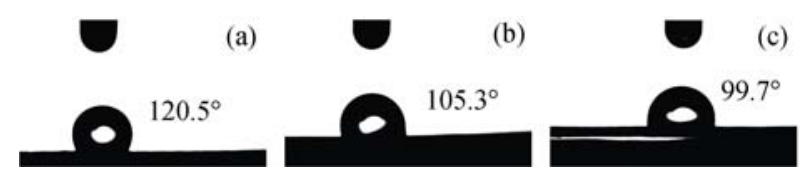

Fig. 3 Cross-sectional views of water droplets on different 
carbon paper

(a) CP; (b) NCP-600; (c) NCP-900

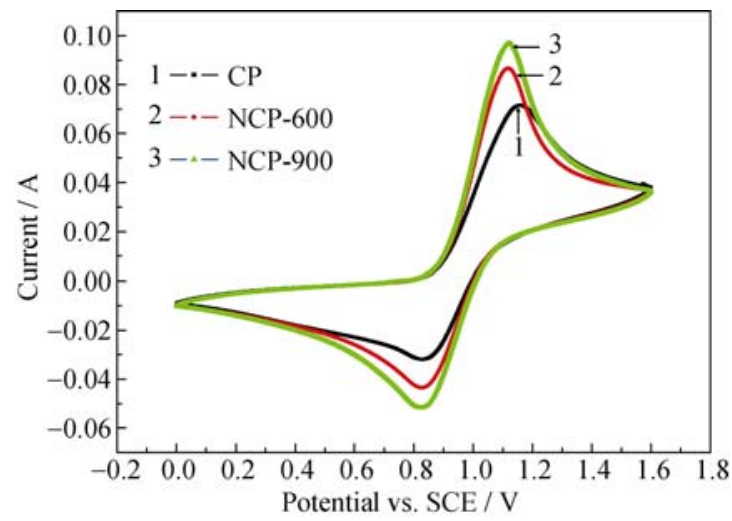

Fig. 4 Cyclic voltammograms of $1.0 \mathrm{~mol} / \mathrm{L} \mathrm{V}(\mathrm{IV})$ in $3.0 \mathrm{~mol} / \mathrm{L}$ $\mathrm{H}_{2} \mathrm{SO}_{4}$ solution with different carbon paper as working electrode

which can increase the effective concentration of vanadium ions on the surface of carbon paper. Therefore, the electrochemical activity and reversibility can be enhanced by heat treatment in atmosphere of $\mathrm{NH}_{3}$.

\subsection{Charge-discharge property}

A typical charge-discharge curve of the cells with $\mathrm{CP}$ and NCP-900 as electrodes respectively is shown in Fig. 5. As observed, the cell with NCP-900 as electrodes exhibits better electrochemical properties, with lower charge plateau and higher discharge plateau. The charge discharge time of the cell with NCP-900 as electrodes is longer than that with CP, which indicates that the cell with NCP-900 has larger discharge capacity.

Figure 6 shows the coulombic and energy efficiencies of the cells with different carbon papers as a function of cycle number at a current density of $20 \mathrm{~mA} / \mathrm{cm}^{2}$. It can be known that the coulombic efficiencies of both cells with $\mathrm{CP}$ and NCP-900 are similar. The average coulombic efficiencies of cells with CP and NCP-900 are $96.70 \%$ and $95.90 \%$, respectively. The energy efficiency of cell with NCP-900 is $83.73 \%, 2.59 \%$ larger than that of the cell with $\mathrm{CP}$. With the structure and materials remaining constant, the changes of energy efficiency can reflect the electrochemical activity of different carbon paper. The results prove that the electrochemical performance of carbon paper has been enhanced by nitrogen doping. The improved electrochemical performance of carbon paper is mainly attributed to the more active sites introduced by nitrogen doping. Moreover, better hydrophilicity provided by the nitrogenous groups is favorable for the mass transfer of vanadium ions.

\section{Conclusions}

An efficient approach based on heat treatment in atmosphere of $\mathrm{NH}_{3}$ is employed to modify the carbon paper efficiently. The results show that the nitrogenous groups can be introduced on the surface of carbon paper successfully, and the wetting property and electrochemical performance can be enhanced significantly. The average energy efficiency of the cell with NCP-900 as electrode at a current density of $20 \mathrm{~mA} / \mathrm{cm}^{2}$ for 50 cycles is $83.73 \%$, $2.59 \%$ larger than that of the cell with pristine sample. The results indicate that nitrogen doping by heat treatment in atmosphere of $\mathrm{NH}_{3}$ might be a promising approach to modify the carbon paper for vanadium redox flow batteries.

Table 1 Relevant data obtained from cyclic voltammetry for $1.0 \mathrm{~mol} / \mathrm{L} \mathrm{V(IV)}$ solution with different carbon paper

\begin{tabular}{ccccc}
\hline Sample & Anodic peak, $I_{\mathrm{pc}} / \mathrm{mA}$ & Cathodic peak, $I_{\mathrm{pc}} / \mathrm{mA}$ & Peak potential interval, $\Delta E_{\mathrm{p}} / \mathrm{mV}$ & $I_{\mathrm{pa}} / I_{\mathrm{pc}}$ \\
\hline CP & 68.9 & 43.1 & 329 & 0.626 \\
NCP-600 & 83.8 & 55.3 & 290 & 0.660 \\
NCP-900 & 92.1 & 62.4 & 297 & 0.678 \\
\hline
\end{tabular}

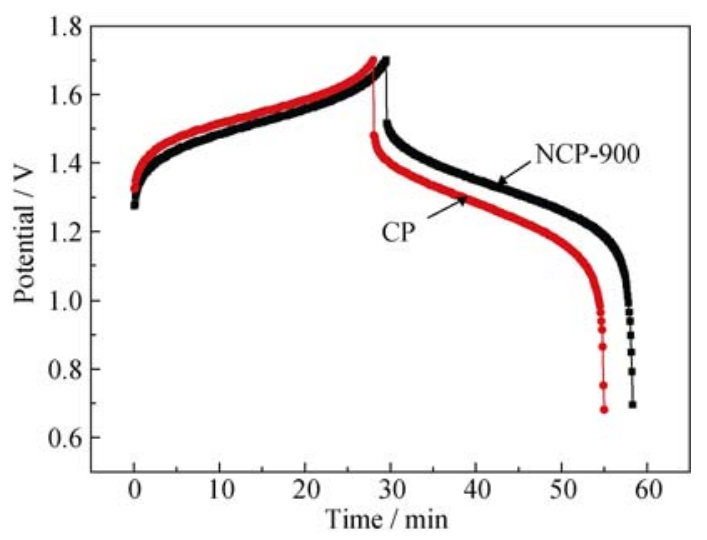

Fig. 5 The $10^{\text {th }}$ charge-discharge curves of the cells employing different carbon papers as electrodes at a current density of $20 \mathrm{~mA} / \mathrm{cm}^{2}$

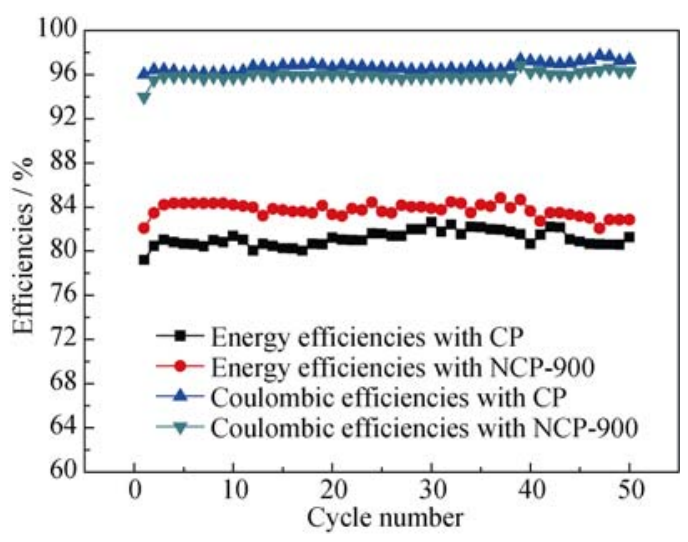

Fig. 6 Efficiencies of cells employing CP and NCP-900 as electrodes at a current density of $20 \mathrm{~mA} / \mathrm{cm}^{2}$ 


\section{References:}

[1] DAI Y M, LIU W J, PAN T C, et al. Surface activation on multiwall carbon nanotube for electrochemical capacitor applications. Applied Surface Science, 2012, 258(7): 3027-3032.

[2] SUN Y, LIU X W, SU W, et al. Studies on ordered mesoporous materials for potential environmental and clean energy applications. Applied Surface Science, 2007, 253(13): 5650-5655.

[3] LI L Y, KIM S, WANG W, et al. A stable vanadium redox-flow battery with high energy density for large-scale energy storage. Advanced Energy Materials, 2011, 1(3): 394-400.

[4] SUZUKI Y, KOYANAGI A, KOBAYASHI M, et al. Novel applications of the flywheel energy storage system. Energy, 2005, 30(11/12): 2128-2143.

[5] HARTIKAINEN T, MIKKONEN R, LEHTONEN J. Environmental advantages of superconducting devices in distributed electricity-generation. Applied Energy, 2007, 84(1): 29-38.

[6] MCMANUS M C. Environmental consequences of the use of batteries in low carbon systems: the impact of battery production. Applied Energy, 2012, 93: 288-295.

[7] RAJU M, KUMAR KHAITAN S. Modeling and simulation of compressed air storage in caverns: a case study of the Huntorf plant. Applied Energy, 2012, 89(1): 474-481.

[8] SUM E, RYCHCIK M, SKYLLAS-KAZACOS M. Investigation of the $\mathrm{V}(\mathrm{V}) / \mathrm{V}(\mathrm{IV})$ system for use in the positive half-cell of a redox battery. Journal of Power Sources, 1985, 16(2): 85-95.

[9] SUM E, SKYLLAS-KAZACOS M. A study of the V(II)/V(III) redox couple for redox flow cell applications. Journal of Power Sources, 1985, 15(2/3): 179-190.

[10] SKYLLAS-KAZACOS M, RYCHCIK M, ROBINS R G, et al. New all-vanadium redox flow cell. Journal of the Electrochemical Society, 1986, 133(5): 1057-1058.

[11] RAHMAN F, SKYLLAS-KAZACOS M. Vanadium redox battery: positive half-cell electrolyte studies. Journal of Power Sources, 2009, 189(2): 1212-1219.

[12] SUN B, SKYLLAS-KAZACOS M. Modification of graphite electrode materials for vanadium redox flow battery application-I. Thermal treatment. Electrochimica Acta, 1992, 37(7): 1253-1260.

[13] KIM S, YAN J, SCHWENZER B, et al. Cycling performance and efficiency of sulfonated poly(sulfone) membranes in vanadium redox flow batteries. Electrochemistry Communications, 2010, 12(11): $1650-1653$.
[14] GONZALEZ Z, BOTAS C, ALVAREZ P, et al. Thermally reduced graphite oxide as positive electrode in vanadium redox flow batteries. Carbon, 2012, 50(3): 828-834.

[15] KAMARUDIN S K, DAUD W R W, HO S L, et al. Overview on the challenges and developments of micro-direct methanol fuel cells (DMFC). Journal of Power Sources, 2007, 163(2): 743-754.

[16] KANEKO H, NOZAKI K, WADA Y, et al. Vanadium redox reactions and carbon electrodes for vanadium redox flow battery. Electrochimica Acta, 1991, 36(7): 1191-1196.

[17] RYCHCIK M, SKYLLAS-KAZACOS M. Evaluation of electrode materials for vanadium redox cell. Journal of Power Sources, 1987, 19(1): $45-54$.

[18] SUN B, SKYLLAS-KAZAKOS M. Chemical modification and electrochemical behaviour of graphite fibre in acidic vanadium solution. Electrochimica Acta, 1991, 36(3/4): 513-517.

[19] SUN B, SKYLlAS-KAZACOS M. Chemical modification of graphite electrode materials for vanadium redox flow battery application-part II. Acid treatments. Electrochimica Acta, 1992, 37(13): 2459-2465.

[20] LI X G, HUANG K L, LIU S Q, et al. Characteristics of graphite felt electrode electrochemically oxidized for vanadium redox battery application. Transactions of Nonferrous Metals Society of China, 2007, 17(1): 195-199.

[21] YUE L, LI W, SUN F, et al. Highly hydroxylated carbon fibres as electrode materials of all-vanadium redox flow battery. Carbon, 2010, 48(11): 3079-3090.

[22] SHAO Y, WANG X, ENGELHARD M, et al. Nitrogen-doped mesoporous carbon for energy storage in vanadium redox flow batteries. Journal of Power Sources, 2010, 195(13): 4375-4379.

[23] WU T, HUANG K L, LIU S Q, et al. Hydrothermal ammoniated treatment of PAN-graphite felt for vanadium redox flow battery. Journal of Solid State Electrochemistry, 2012, 16: 579-585.

[24] LIU S Q, SHI X H, HUANG K L, et al. Characteristics of carbon paper as electrode for vanadium redox flow battery. Chinese Journal of Inorganic Chemistry, 2008, 24(7): 1079-1083.

[25] LIU S Q, SHI X H, HUANG K L, et al. Characteristics of carbon paper as electrode for vanadium redox flow battery. Journal of Inorganic Materials, 2009, 24(4): 798-802.

[26] HE Z X, SU A Q, GAO C, et al. Carbon paper modified by hydrothermal ammoniated treatment for vanadium redox battery. Ionics, 2013, 19: 1021-1026.

[27] YAO Y L, DING Y, YE L S, et al. Two-step pyrolysis process to synthesize highly dispersed Pt-Ru/carbon nanotube catalysts for methanol electrooxidation. Carbon, 2006, 44(1): 61-66. 


\title{
全钒液流电池用碳纸电极掺氮改性的研究
}

\author{
何章兴 $^{1,2}$, 刘剑蕾 ${ }^{2}$, 何 震 $^{2}$, 刘素琴 ${ }^{2}$
}

(1. 河北联合大学 化学化工学院, 唐山 063009; 2. 中南大学 化学化工学院, 教育部有色金属资源化学重点实验室, 长沙 410083)

摘 要: 采用在氨气氛下加热(NCP-600: $600^{\circ} \mathrm{C}$ 下处理, NCP-900: $900^{\circ} \mathrm{C}$ 下处理)对全钒液流电池碳纸电极进行掺氮改性 处理。通过此改性处理，含氮官能团成功地引入到碳纸表面。掺氮处理改善了碳纸表面的亲水性, NCP-900 的接触角 相比于空白碳纸由 $120.5^{\circ}$ 降到 $99.7^{\circ}$, 且对表面形貌没有明显影响, 不会影响其机械性能。同时, 掺氮处理能明显地增 强碳纸的电化学活性, 循环伏安测试中, NCP-900 的 V(IV)/V(V)电对氧化峰为 $92.1 \mathrm{~mA}$, 远高于空白碳纸 $(68.9 \mathrm{~mA})$ 。由 NCP-900 和空白碳纸组装成电池考察了其充放电性能, 在 $20 \mathrm{~mA} / \mathrm{cm}^{2}$ 下进行充放电，由 NCP-900 组装的电池其能量效 率为 $83.73 \%$, 较空白电池高 $2.59 \%$ 。掺氮改性处理提高碳纸的电化学性能主要是由于钒电对活性位点的增加和亲水 性能的增强。

关 键 词: 全钒液流电池; 掺氮; 碳纸; 动力学

中图分类号: TQ174

文献标识码: A 